\title{
Możliwości wykorzystania destylatów alkoholowych jako paliwa opałowego
}

\section{Possibilities of using alcohol distillates as heating fuel}

\author{
Maciej Basiura, Urszula Żyjewska, Tomasz Siuda \\ Instytut Nafty i Gazu - Państwowy Instytut Badawczy
}

\begin{abstract}
STRESZCZENIE: W związku z rosnącym zapotrzebowaniem na szeroko rozumianą czysta energię trwają poszukiwania paliw zeroemisyjnych (niepowodujących zwiększenia ilości gazów cieplarnianych emitowanych do atmosfery). Inicjatywy ograniczenia wykorzystania węgla, podejmowane w Europie i na świecie, skłaniają do zastosowania bioalkoholi jako paliw, a także przewidują wzrost wykorzystania tego rodzaju paliwa. W artykule zaprezentowano technologie produkcji wybranych mieszanin alkoholowych. Opisano sposoby otrzymywania alkoholi metodami tradycyjnymi (fermentacja alkoholowa) z surowców pochodzenia rolniczego, to jest zbóż i roślin bulwiastych. Ponadto scharakteryzowano poszczególne etapy produkcji. Przedstawiono również możliwość wykorzystania surowców odpadowych zawierających kompleks lignocelulozowy do produkcji alkoholu etylowego. Opisano budowę kompleksu lignocelulozowego, etapy produkcji oraz główne problemy procesu wytwarzania etanolu z tego typu surowców. Zwrócono uwagę na trwające poszukiwania metod produkcji alkoholu etylowego w reakcjach chemicznych (np. z wykorzystaniem nanokatalizatorów), w których substratem są gazy cieplarniane (przede wszystkim tlenek węgla(IV)). Przeprowadzono analizę przepisów i obostrzeń prawnych mogących mieć wpływ na możliwość wykorzystania destylatów alkoholowych (bioetanolu, spirytusu, alkoholu etylowego, alkoholu metylowego i ich mieszanin) w celach opałowych. W analizie rozważano przepisy krajowe i unijne, ponieważ Polska jest krajem członkowskim Unii Europejskiej. Ponadto przedstawiono sposoby wykorzystania destylatów alkoholowych (alkoholu etylowego, spirytusu, bioetanolu) jako komponentu mieszanek paliwowych lub samoistnego paliwa. Scharakteryzowano proces spalania wybranych destylatów alkoholowych z uwzględnieniem środków skażających. Zaprezentowano porównanie współczynników emisji zanieczyszczeń w zależności od spalanego paliwa w sektorze gospodarstw domowych. Wyróżniono dwie grupy urządzeń użytku domowego zasilanych paliwem alkoholowym, a w tym momencie dostępnych na rynku dla konsumenta. Opisano ich możliwości oraz ograniczenia zastosowania, funkcjonalności, podano dostępne moce cieplne. We wnioskach podsumowano wyniki przeprowadzonych analiz: metod produkcji destylatów alkoholowych oraz przepisów prawnych (krajowych i unijnych). Ponadto autorzy przewidują rozwój produkcji i wykorzystania alkoholu etylowego w celach opałowych.
\end{abstract}

Słowa kluczowe: alkohol, paliwo zeroemisyjne, biopaliwo opałowe.

ABSTRACT: Growing demand for widely understood clean energy cause the search for zero-emission fuels (not increasing the amount of greenhouse gases emitted to the atmosphere). Undertaken in Europe and in the world initiatives in limiting the use of coal tend to use bioalcohols as fuels and predict an increase of usage of this type of fuel. The article presents production technologies of selected alcohol mixtures. Raw materials, particular stages of production were characterized in the article. In addition, the possibility of using waste raw materials containing a lignocellulose complex for the production of ethyl alcohol was also presented. The structure of the lignocellulose complex, production stages and main problems of the ethanol production process from this type of raw materials were described. Attention was drawn to the ongoing research for methods to produce ethyl alcohol in chemical reactions (e.g. by using nanocatalysts), in which greenhouse gases (carbon dioxide) are the substrate. An analysis of regulations and legal restrictions that may affect the possibility of using alcohol distillates (bioethanol, spirit, ethyl alcohol, methyl alcohol and mixtures thereof) for heating purposes was carried out. Since Poland is a member state of the European Union, the analysis considered national and EU regulations. In addition, ways of using alcohol distillates (ethyl alcohol, spirit, bioethanol) as a component for fuel mixtures or spontaneous fuel were presented. The combustion process of selected alcoholic distillates, with or without contaminants, was characterized. Emission factor for different emissions in the household sector depending on burned fuel were presented. Two groups of household appliances powered with alcohol fuel, currently available to consumers on the market, were distinguished. Their possibilities and limitations of use, functionality were described. In conclusions, the results of the analyses methods of alcoholic distillate production and legal provisions (national and EU) were summarized. In addition, the authors predict the positive impact of the production and usage of ethyl alcohol for heating purposes.

Key words: alcohol, zero-emission fuel, biofuel.

Autor do korespondencji: M. Basiura, e-mail: maciej.basiura@inig.pl

Artykuł nadesłano do Redakcji: 06.11.2019 r. Zatwierdzono do druku: 27.02.2020 r. 


\section{Wstęp}

Wykorzystanie ropy naftowej czy węgla kamiennego rozwinęło wiele światowych gospodarek oraz przyspieszyło postęp technologiczny i maszynowy. Jednakże zasoby paliw kopalnych nie odnawiają się w krótkim czasie, a ich ciągła i wzrastająca konsumpcja zmniejsza dostępną ilość. Ponadto stosowanie tych paliw generuje emisje różnych substancji do atmosfery, nierzadko szkodliwych, powodujących zanieczyszczenie i degradację środowiska. Dlatego w ostatnich latach poszukiwane są czyste, odnawialne, zeroemisyjne źródła energii i paliw, pozwalające ograniczyć wykorzystanie paliw konwencjonalnych. Gospodarka zeroemisyjna, neutralna węglowo, staje się wyzwaniem, celem i priorytetem dla wielu krajów świata. Konieczność kontrolowania i ograniczania emisji gazów cieplarnianych spowodowała, że zagospodarowanie tlenku węgla(IV) stało się kwestią globalną. W związku z rosnącym zapotrzebowaniem rynku na szeroko rozumianą czystą energię trwają poszukiwania paliw zeroemisyjnych (niepowodujących zwiększania ilości gazów cieplarnianych w atmosferze ziemskiej) i odnawialnych źródeł energii (Holewa et al., 2012; Piskowska-Wasiak, 2018; Rogowska, 2018). Jednym $z$ nich jest szeroko rozumiana biomasa. Biomasę traktuje się jako paliwo/źródło odnawialne, ponieważ w relatywnie krótkim czasie można je ponownie uzyskać w formie przydatnej do wytworzenia energii mechanicznej, elektrycznej czy ciepła. Biomasa, w stanie stałym, to między innymi: drewno, rośliny pochodzące z upraw energetycznych, biomasa przetworzona, np. pellet i brykiety, odpady i pozostałości pochodzenia biologicznego, ulegające biodegradacji z przemysłu lub produkcji rolnej. Szczegółowo pojęcie biomasy definiują akty prawne. Poza energetycznym wykorzystaniem biomasa stosowana jest do produkcji biopłynów i biogazu. Badania wykazują, że z powodzeniem można spalać biogaz rolniczy (mieszanina oczyszczonego biogazu i LNG lub LPG) w urządzeniach użytku domowego oraz urządzeniach do zastosowań przemysłowych (Wojtowicz, 2014; Siuda i Wojtowicz, 2016).

\section{Produkcja alkoholu}

Sposobów otrzymywania alkoholi jest wiele. Na skalę przemysłową otrzymuje się je syntetycznie, w reakcjach syntezy, uwodornienia, uwodnienia, z wykorzystaniem różnych katalizatorów. Niekiedy są to złożone reakcje, wymagające odpowiednich warunków. Metanol dawniej otrzymywało się poprzez rozkładową destylację drewna, dlatego alkohol ten często nazywany jest spirytusem drzewnym. Obecnie wytwarza się go syntetycznie w reakcji katalitycznej uwodornienia tlenku węgla pod zwiększonym ciśnieniem, w temperaturze $300-400^{\circ} \mathrm{C}$ (Encyklopedia PWN).
Najpowszechniejszą metodą otrzymywania etanolu jest fermentacja alkoholowa surowców zawierających cukry. Mogą to być surowce roślinne, rolnicze, zawierające skrobię. Proces technologiczny produkcji destylatu rolniczego polega na przygotowaniu i przekształceniu surowca w postać przydatną do fermentacji alkoholowej, a następnie odpędzaniu z zacieru otrzymanego etanolu (Biernacka, 2012). Kolejnym etapem w produkcji etanolu jest proces destylacji, w którym otrzymuje się surówkę - destylat rolniczy zawierający $80-90 \%$ etanolu oraz wywar gorzelniczy (Paszkowski i Rautenstrauch, 1961; Gogolewski, 1962). Wywar gorzelniczy wykorzystuje się jako komponent mieszanek paszowych dla zwierząt gospodarskich. Surówkę poddaje się dalszemu procesowi rektyfikacji, aby uzyskać spirytus rektyfikowany (96-proc. roztwór etanol-woda) (Lewicki, 2017).

Opracowywane są metody produkcji etanolu z innych typów surowców, np. zawierających kompleks lignocelulozowy, który pozyskiwany jest $\mathrm{z}$ twardego drewna, roślin zielarskich lub uprawnych, odpadów z produkcji papieru. Kompleks lignocelulozy stanowi skomplikowany układ składający się głównie z trzech frakcji: celulozowej (40-55\% suchej masy), hemicelulozowej (24-40\% suchej masy) i ligninowej (18-25\% suchej masy) (Leja et al., 2009). Lignina to makromolekuła o charakterze fenolowym, a celuloza i hemiceluloza są to długołańcuchowe polisacharydy. Złożona budowa stanowi niedogodność w konwersji surowca. Podobnie jak przy produkcji alkoholu etylowego, opisanej we wcześniejszym akapicie, należy doprowadzić surowiec do postaci przydanej w procesie fermentacji alkoholowej. Dlatego pierwsze dwa etapy procesu biokonwersji lignocelulozy to obróbka wstępna i hydroliza, następnie fermentacja alkoholowa, a ostatni etap - oczyszczenie produktu końcowego. Problemem w produkcji etanolu z surowców celulozowych jest również dobór odpowiednich mikroorganizmów fermentujących pentozy i heksozy (mieszanina cukrów prostych otrzymywana przez hydrolizę surowca celulozowego). Dobrze poznane są mikroorganizmy fermentujące heksozy, takie jak drożdże Saccharomyces cerevisiae lub bakterie Zymomonas mobilis. Są one wykorzystywane od wielu lat w produkcji napojów alkoholowych. Problem stanowi znalezienie mikroorganizmów zdolnych do fermentacji obydwu typów cukrów. Brak naturalnych mikroorganizmów spowodował, że naukowcy próbują skonstruować organizmy o pożądanych cechach z wykorzystaniem techniki inżynierii metabolicznej i inżynierii genetycznej. Udoskonalane są metody produkcji bioetanolu z tego typu surowców, szczególnie na potrzeby biokomponentów i biopaliw, mających ograniczyć wykorzystanie paliw kopalnych oraz emisję tlenku węgla(IV).

Jako paliwo lub komponent do paliw benzynowych alkohol etylowy produkowany jest $\mathrm{z}$ dwóch grup surowców. Pierwsza $\mathrm{z}$ nich to surowce jadalne, spożywcze, pochodzenia rolniczego 
zawierające skrobię, tj. zboża i rośliny bulwiaste (np. buraki). Bioetanol otrzymywany z takich surowców nazywany jest paliwem pierwszej generacji. Produkcja etanolu z surowców spożywczych na cele energetyczne czy paliwowe może budzić pytania o ewentualne ograniczenia w produkcji żywności lub zmniejszenie jej zapasów, a także o wzrost cen produktów żywnościowych. Rozwiązaniem jest wykorzystanie grupy surowców odpadowych, niejadalnych, różnego pochodzenia (np. makulatura, drewno odpadowe). Biopaliwa otrzymywane z surowców odpadowych nazywane są biopaliwami drugiej generacji.

Naukowcy z Laboratorium Oak Ridge (ORNL - Oak Ridge National Laboratory) w Stanach Zjednoczonych, wykorzystując katalizator wykonany w nanotechnologii, otrzymali etanol bezpośrednio z tlenku węgla(IV), wywołując skomplikowaną reakcję chemiczną, która zasadniczo odwraca proces spalania. W procesie spalania alkoholu w obecności tlenu produktami reakcji jest tlenek węgla(IV) i para wodna. Naukowcy z laboratorium ORNL przekształcili wodny roztwór tlenku węgla(IV) w etanol w reakcji z wykorzystaniem napięcia elektrycznego i nanocząsteczkowego katalizatora. Materiałami zastosowanymi do budowy katalizatora są: węgiel, miedź i azot. Nanocząsteczki miedzi zostały osadzone w strukturze węgla. Wstępna analiza sugeruje, że chropowata, kolczasta powierzchnia katalizatorów dostarcza wiele miejsc reaktywnych, co ułatwia konwersję. Wydajność procesu wyniosła 63\%. Metoda ta opiera się na niedrogich materiałach w porównaniu z reakcjami syntezy, w których katalizatorem jest rod albo platyna. Ponadto zachodzi w temperaturze pokojowej. Dzięki tym zaletom naukowcy są przekonani, że metodę otrzymywania etanolu z zastosowaniem nanotechnologicznego katalizatora można wykorzystać w skali przemysłowej. Więcej o przeprowadzonych eksperymentach napisali Song et al. (2016) i Rondinone (2016).

\section{Analiza przepisów prawnych}

Polskę jako państwo członkowskie Unii Europejskiej obowiązują, poza krajową legislacją, dyrektywy i rozporządzenia Parlamentu Europejskiego i Rady Europy. Wszystkie substancje chemiczne produkowane na terenie Unii Europejskiej lub do niej importowane w ilości powyżej 1 tony rocznie podlegają Rozporządzeniu (WE) nr 1907/2006 Parlamentu Europejskiego i Rady z dnia 18 grudnia 2006 r. w sprawie rejestracji, oceny, udzielania zezwoleń i stosowanych ograniczeń w zakresie chemikaliów (REACH) i utworzenia Europejskiej Agencji Chemikaliów, zmieniającemu dyrektywę 1999/45/WE oraz uchylającemu rozporządzenie Rady (EWG) nr 793/93 i rozporządzenie Komisji (WE) nr 1488/94, jak również dyrektywę Rady 76/769/EWG i dyrektywy Komisji 91/155/EWG, 93/67/ EWG, 93/105/WE i 2000/21/WE. Alkohole, jako substancje niebezpieczne, podlegają również Rozporządzeniu Ministra Gospodarki z dnia 29 stycznia 2013 r. w sprawie ograniczeń produkcji, obrotu lub stosowania substancji i mieszanin niebezpiecznych lub stwarzających zagrożenie oraz wprowadzania do obrotu lub stosowania wyrobów zawierających takie substancje lub mieszaniny.

Produkcja spirytusu w gorzelniach jest regulowana Ustawą z dnia 2 marca 2001 r. o wyrobie alkoholu etylowego oraz wytwarzaniu wyrobów tytoniowych. Wyżej wymieniona ustawa „określa zasady i warunki podejmowania i wykonywania działalności gospodarczej w zakresie wyrobu alkoholu etylowego i jego skażania (...)", a w art. 2 ust 1. definiuje alkohol etylowy jako ,płyn alkoholowy uzyskany w wyniku destylacji po fermentacji alkoholowej produktów rolniczych albo płyn alkoholowy uzyskany w sposób syntetyczny" (Ustawa z 2 marca 2001). Uzupełnieniem wyżej wymienionej ustawy jest Rozporządzenie Ministra Rolnictwa i Rozwoju Wsi z dnia 25 czerwca 2008 r. w sprawie środków dopuszczonych do skażania alkoholu etylowego.

Alkohol etylowy jako składnik lub samoistne paliwo podlega ustawom związanym z paliwami: Ustawie z dnia 10 kwietnia 1997 r. - Prawo energetyczne, Ustawie z dnia 11 stycznia 2018 r. o elektromobilności i paliwach alternatywnych. Ponieważ może być wytwarzany z biomasy, obejmuje go również Ustawa z dnia 15 lutego 2015 r. o odnawialnych źródłach energii. W art. 2 ust. 4 tej ustawy podano następującą definicję „biopłyny - ciekłe paliwa dla celów energetycznych innych niż w transporcie, w tym do wytwarzania energii elektrycznej lub ciepła, wytworzone z biomasy, wykorzystywane w instalacjach spełniających wymagania w zakresie standardów emisyjnych, o ile takie standardy zostały określone na podstawie przepisów o ochronie środowiska" (Ustawa z 15 lutego 2015). Tak definiowane biopłyny jak najbardziej mogą być wykorzystane w celach energetycznych, np. opałowych lub do produkcji energii elektrycznej. Biopłyny, w rozumieniu ww. ustawy, muszą być wytwarzane z biomasy, która jest zdefiniowana dość szeroko.

Analizując powyższe ustawy i rozporządzenia nie stwierdza się, aby stosowanie etanolu (alkoholu etylowego) lub spirytusu było wyłączone lub zabronione w celach energetycznych. Co więcej, ustawa (Ustawa z 15 lutego 2015) definiuje biopłyny i biokomponenty do celów energetycznych oraz przewiduje takie zastosowanie. Aby ułatwić wykorzystanie etanolu w celach energetycznych, w prawie krajowym powinno pojawić się więcej przepisów definiujących destylaty i rektyfikaty, określających zasady i warunki zastosowania i wykorzystania. Jedynie rozporządzenie Ministra Gospodarki (Rozporządzenie z 29 stycznia 2013) w § 2a ust. 1 wyłącza z obrotu (polegającego na sprzedaży dla konsumentów) na terytorium Rzeczypospolitej Polskiej metanol oraz substancje i mieszaniny zawierające metanol w stężeniach większych niż 3\% wagowych. W kolejnym 
ustępie ww. rozporządzenia wymieniono substancje lub mieszaniny, dla których $\S 2$ a ust. 1 nie ma zastosowania. Są to paliwa wykorzystywane do ogniw paliwowych, silników stosowanych w modelarstwie i sportach motorowodnych, biopaliw ciekłych (o których mowa w Ustawie z dnia 25 sierpnia 2006 r. o biokomponentach i biopaliwach ciekłych). W związku z tym czysty metanol nie może być brany pod uwagę jako paliwo opałowe w świetle aktualnego prawodawstwa.

\section{Spalanie}

Metanol i etanol są cieczami łatwopalnymi. Spalają się w powietrzu błękitnym, ledwo zauważalnym płomieniem. Ze względu na proces produkcji łatwo utrzymać czystość tego paliwa, dlatego w spalinach brak jest związków siarki. Przy dobrze prowadzonym procesie spalania alkoholu spaliny zawierają parę wodną i tlenek węgla (IV) oraz stosunkowo małą zawartość tlenków azotu. Po wypaleniu paliwa nie pozostaje żaden dodatkowy odpad, np. popiół, a w spalinach nie ma cząstek stałych (pyły). Na rysunku 1 przedstawiono wartości współczynników emisji zanieczyszczeń (tlenki azotu, tlenek węgla oraz pył PM10 i PM2.5) dla najpopularniejszych paliw opałowych wykorzystywanych w gospodarstwach domowych (European Commission, 2015; Zyśk i Suwała, 2017).

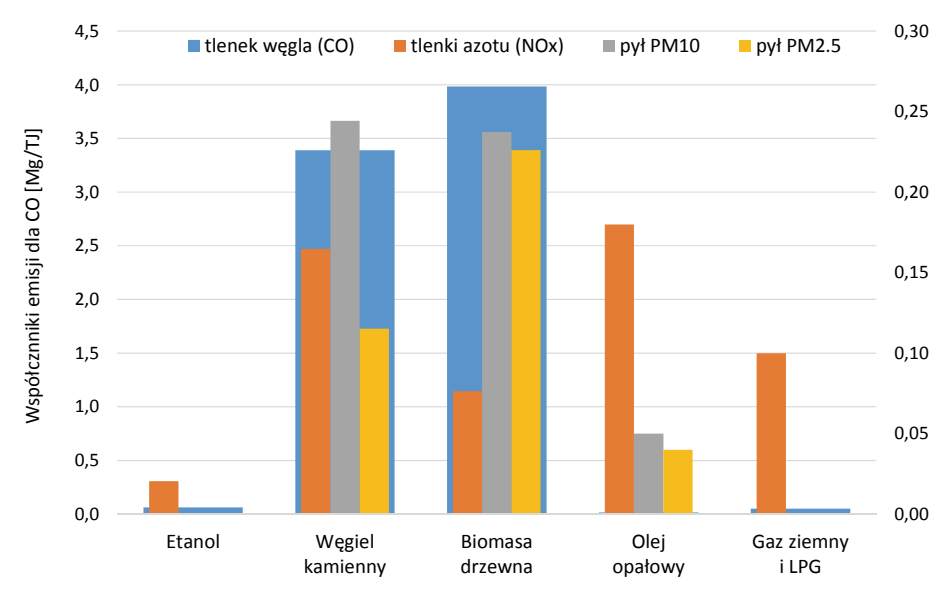

Rys. 1. Współczynniki emisji dla różnych zanieczyszczeń w zależności od spalanego paliwa w sektorze gospodarstw domowych

Fig. 1. Emission factor for different emissions in the household sector depending on the fuel burned

Najwyższe współczynniki emisji zanieczyszczeń mają paliwa stałe (węgiel kamienny, biomasa drzewna). Emisja z urządzeń zasilanych etanolem kształtuje się na podobnym poziomie jak w przypadku spalania paliw gazowych w typowych urządzeniach sektora gospodarstw domowych. Na podkreślenie zasługuje fakt, że w przypadku etanolu widoczna jest wyraźnie niższa emisja NOx.
Alkohol przeznaczony do celów przemysłowych lub opałowych jest znacznie tańszy od napojów alkoholowych, ponieważ jest skażony. Wykaz środków dopuszczonych do skażania alkoholu etylowego zawarto w rozporządzeniu Ministra Rolnictwa i Rozwoju Wsi (Rozporządzenie z 25 czerwca 2008). Załącznik określa również minimalną ilość, jaką powinno się skażać etanol, w odniesieniu do jednostki objętości. Analizując wykaz, można zauważyć, że większość dopuszczonych substancji to związki zawierające w swojej strukturze wyłącznie atomy węgla, wodoru i tlenu. Dodawane do etanolu, tworzą mieszaniny, nie wprowadzając składników, które podczas spalania mogą tworzyć niepożądane produkty w spalinach.

Paliwa etanolowe, z uwagi na czystość spalania oraz dużą gamę surowców, z których mogą być produkowane, znajdują zastosowanie jako dodatek do paliw transportowych lub są wykorzystywane jako samoistne paliwo. Samochody zasilane paliwami z domieszką etanolu (lub bioetanolu) nie są nowością. Dość dobrze poznano wpływ takich mieszanek na silniki samochodowe (Żółty i Stępień, 2016; Pałuchowska i Stępień, 2017; Żółty i Sacha, 2018). Paliwo z dodatkiem etanolu (do 10\%) dostępne jest na stacjach benzynowych w krajach Unii Europejskiej. Przewiduje się rozszerzenie wykorzystania bioetanolu jako dodatku do benzyn, oleju napędowego, ponieważ pozwala to na zmniejszenie zużycia stosowanych paliw konwencjonalnych. Od wielu lat bioetanol wykorzystywany jest jako dodatek do paliw silnikowych w Brazylii i Zimbabwe. W krajach Ameryki Południowej, gdzie tanio uzyskiwany jest etanol z kukurydzy lub trzciny cukrowej, zastąpił on w znacznej mierze olej napędowy i benzynę stosowaną do zasilania silników samochodowych (Danek, 2015).

\section{Wykorzystanie w gospodarstwach domowych}

Wśród urządzeń gospodarstwa domowego zasilanych etanolem, a dostępnych na rynku można wyróżnić dwie grupy. Są to kominki na paliwa ciekłe, tzw. biokominki, oraz kuchenki spirytusowe.

Na rysunku 2 zaprezentowano przykład biokominka $\mathrm{z}$ efektem dekoracyjnym zasilanego etanolem (bioetanolem). Efekt ozdobny stanowi płomień spalanego paliwa na specjalnie zaprojektowanym i przygotowanym palniku. Zasada działania palnika jest dość prosta. Bioetanol znajdujący się w zbiorniku biokominka jest podgrzewany i odparowuje, a następnie pary paliwa zostają zapalone.

Jeśli biokominek posiada możliwość regulacji wielkości płomienia, a co za tym idzie - obciążenia cieplnego, reakcja na sterowanie nie jest natychmiastowa i zależy od temperatury paliwa, czyli szybkości jego odparowywania. Zakończenie pracy biokominka wymaga wypalenia par paliwa i zaniku 


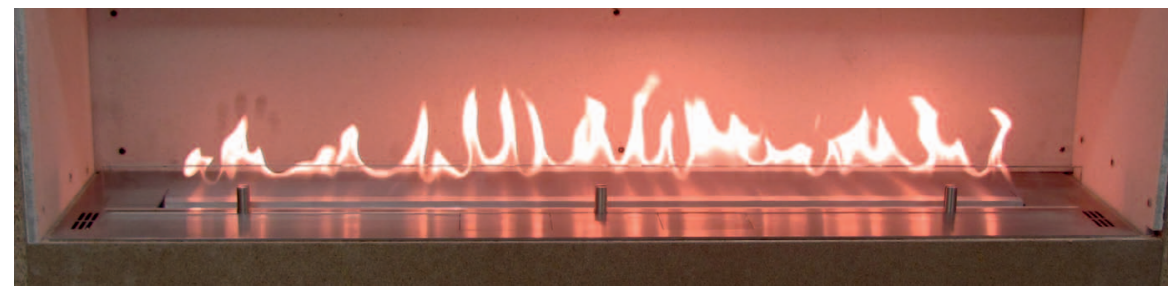

Rys. 2. Kominek na paliwo ciekłe

Fig. 2. Liquid fuel fireplace

płomienia. Ponowne rozpalenie jest możliwe po ostygnięciu elementów palnika.

Forma wykonania biokominka może przypominać tradycyjny kominek wolnostojący lub do zabudowy, opalany paliwem stałym, jak również urządzenie może być w formie designerskiej. Na rynku dostępne są specjalnie przygotowane biopaleniska z zestawem akcesoriów umożliwiające przeróbkę palenisk tradycyjnych kominków (Lovter). Zestawy takie są ciekawą alternatywą dla urządzeń opalanych paliwami stałymi z uwagi na postępujące zakazy spalania drewna w kominkach oraz uciążliwy smog powstający przy spalaniu paliw stałych. Forma i wielkość dostępnych biokominków zależą tylko od pomysłowości projektantów i potrzeb rynku. Jedynym ograniczeniem zawartym w przepisach jest maksymalna moc cieplna, która nie może być większa niż 4,5 kW (PN-EN 16647:2015). Stosunkowo małe moce cieplne dostępnych urządzeń uniemożliwiają używanie ich jako głównego źródła ciepła w mieszkaniu lub domu jednorodzinnym.

Drugą grupą urządzeń wykorzystujących etanol są kuchenki. Kuchenki spirytusowe dostępne są przeważnie jako palniki turystyczne, nieposiadające regulacji mocy, bądź przenośne kuchenki jednopalnikowe. Nieliczni producenci oferują jedno- lub dwupalnikowe płyty kuchenne do wbudowania zasilane paliwem alkoholowym. Kuchenki i płyty posiadają palniki o mocy około $2 \mathrm{~kW}$. Należy zaznaczyć, że funkcjonalność kuchenek spirytusowych nie odbiega od funkcjonalności kuchenek gazowych o palnikach analogicznej mocy. Kuchenki zasilane etanolem stanowią alternatywę dla gospodarstw domowych wykorzystujących do przyrządzania posiłków paliwa stałe, między innymi w państwach Afryki (Etiopia). Ponieważ kraje Afryki, szczególnie mniej zamożne, posiadają słabo rozwiniętą sieć elektroenergetyczną, a warunki klimatyczne i brak koniecznej infrastruktury uniemożliwiają wykorzystanie gazu ziemnego i jego pochodnych, kuchenki spirytusowe mogą zastąpić nieekologicznie kuchenki węglowe (Takama et al., 2011; Benka-Coker et al., 2018).

Obecnie brak jest na rynku urządzeń grzewczych opalanych paliwem na bazie alkoholu, wytwarzających ciepło na potrzeby centralnego ogrzewania lub ciepłej wody użytkowej, które mogłyby stanowić główne lub jedyne źródło ciepła w gospodarstwie domowym, w warunkach klimatycznych Polski.
Istotną cechą funkcjonalną tego typu urządzenia powinno być zmienne obciążenie cieplne palnika, w zakresie od kilku do kilkudziesięciu kilowatów. Konstrukcja takich urządzeń powinna zapewniać funkcjonalność i bezpieczeństwo użytkowania znane $\mathrm{z}$ urządzeń gazowych dostępnych na rynku.

\section{Podsumowanie}

Inicjatywy ograniczenia użycia węgla podejmowane w Europie i na świecie skłaniają się do zastosowania bioalkoholi jako paliw, a także przewidują wzrost wykorzystania tego rodzaju paliwa. Polskie i unijne prawo umożliwia stosowanie paliw na bazie alkoholu do celów grzewczych. Na terenie Polski paliwo opałowe (na potrzeby energetyczne, a nie transportowe) dostępne na rynku konsumenckim nie może, ze względów bezpieczeństwa, zawierać więcej niż 3\% metanolu.

Sposób otrzymywania paliw na bazie etanolu gwarantuje jego „czysty” skład. Dodawane do bioetanolu środki skażające nie wprowadzają składników, które podczas spalania mogą tworzyć niepożądane produkty w spalinach. Przeprowadzone analizy, a także doświadczenia i badania urządzeń spalających bioetanol wykazują, że skład spalin z odpowiednio zaprojektowanego urządzenia nie odbiega pod względem zawartości szkodliwych składników i gazów cieplarnianych od tego z urządzeń gazowych.

Wykorzystanie destylatów alkoholowych (w tym etanolu) w celach energetycznych może być uzasadnione w miejscach, gdzie lokalne władze mają problem z utrzymaniem czystości powietrza, szczególnie w miejscowościach uzdrowiskowych lub sanatoryjnych, a także na terenach, gdzie wprowadzane są zakazy wykorzystania paliw stałych (węgiel kamienny, drewno itd.) lub olejów opałowych, a rozwój gazociągów nie jest możliwy (np. z racji dużych nakładów inwestycyjnych, czasu realizacji, ukształtowania terenu).

Obecnie koszt wytworzenia energii lub ciepła ze spalania paliwa na bazie etanolu jest nawet kilkakrotnie wyższy niż koszt energii z paliw konwencjonalnych. Można założyć, że cena bioetanolu będzie spadać w przypadku większego zainteresowania konsumentów tym rodzajem paliwa. Można również przewidywać obniżenie ceny w związku z wykorzystaniem do produkcji etanolu surowców odpadowych przemysłu rolnego, które muszą być odpłatnie utylizowane. Zastosowanie technologii produkcji bioetanolu, w wyniku której powstają również inne półprodukty, np. przy produkcji pasz dla zwierząt, będzie miało pozytywny wpływ na spadek ceny. W związku z walką z efektem cieplarnianym, emisją pyłów i gazów cieplarnianych, a także z powodu zmniejszania udziału paliw kopalnych w szeroko rozumianej energetyce - należy przewidywać 
wprowadzenie dotacji rządowych dla producentów biopaliw opałowych lub konsumentów korzystających z urządzeń grzewczych opalanych biopaliwami.

Artykuł powstał na podstawie pracy statutowej pt.: Możliwości wykorzystania destylatów alkoholowych jako paliwa opałowego - praca INiG - PIB na zlecenie MNiSW; nr zlecenia: 0083/ GU/2019, nr archiwalny: DK-4100-0072/2019.

\section{Literatura}

Benka-Coker M., Tadele W., Milano A., Getaneh D., Stokes H., 2018. A case study of the ethanol CleanCook stove intervention and potential scale-up in Ethiopia. Energy for Sustainable Development, 46: 53-64. DOI: 10.1016/j.esd.2018.06.009.

Biernacka P., 2012. Metody kompleksowej analizy składu produktów ubocznych procesu fermentacji alkoholowej w półproduktach i produktach spirytusowych. Rozprawa doktorska. Politechnika Gdańska, Gdańsk.

Danek B., 2015. Biopaliwo o zawartości 20 $\div 25 \%$ (V/V) etanolu, wybrane właściwości fizykochemiczne. Nafta-Gaz, 4: 223-229.

Encyklopedia PWN. <https://encyklopedia.pwn.pl> (dostęp: wrzesień 2019).

European Commission, 2015. Study on alcohol-powered flueless fireplace combustion and its effects on indoor air quality, Final Report. DOI: $10.2818 / 457904$.

Gogolewski M., 1962. Technologia chemiczna ogólna. Część II. Państwowe Wydawnictwa Szkolnictwa Zawodowego, Warszawa.

Holewa J., Kukulska-Zając E., Pęgielska M., 2012. Analiza możliwości wprowadzania biogazu do sieci przesyłowej. Nafta-Gaz, 8: 523-529.

Leja K., Lewandowicz G., Grajek W., 2009. Produkcja bioetanolu z surowców celulozowych. Biotechnologia, 4(87): 88-101.

Lewicki P. (red.), 2017. Inżynieria procesowa i aparatura przemysłu spożywczego. WNT, Warszawa.

Lovter, Pierwsza międzynarodowa gazeta o biokominkach. $<$ http://biokominek.org> (dostęp: wrzesień 2019).

Pałuchowska M., Stępień Z., 2017. Oceny paliw etanolowych w testach silnikowych i eksploatacyjnych. Nafta-Gaz, 2: 97-104. DOI: 10.18668/NG.2017.02.04.

Paszkowski M., Rautenstrauch S., 1961. Chemia organiczna. WNT, Warszawa.

Piskowska-Wasiak J., 2018. Możliwości komplementarnego wykorzystania gazu ziemnego i odnawialnych źródeł energii. Nafta-Gaz, 4: 290-297. DOI: 10.18668/NG.2018.04.053.

Rogowska D., 2018. Produkcja biopaliw jako element gospodarki o obiegu zamkniętym. Nafta-Gaz, 2: 156-163. DOI: 10.18668/NG.2018.02.10.

Rondinone A., 2016. Nano-spike Catalysts Convert Carbon Dioxide Directly into Ethanol. <https://www.ornl.gov/news/nano-spike-catalysts-convertcarbon-dioxide-directly-ethanol> (dostęp: wrzesień 2019).

Siuda T., Wojtowicz R., 2016. Badania możliwości współspalania biogazu rolniczego i LNG lub LPG w urządzeniach użytku domowego oraz w urządzeniach do zastosowań przemysłowych. Nafta-Gaz, 9: 747-754. DOI: 10.18668/NG.2016.09.10.

Song Y., Peng R., Hensley D.K., Bonnesen P.V., Liang L., Wu Z., Meyer III H.M., Chi M., Ma Ch., Sumpter B.G., Rondinone A.J., 2016. High-Selectivity Electrochemical Conversion of $\mathrm{CO}_{2}$ to Ethanol using a Copper Nanoparticle/N-Doped Graphene Electrode. Chemistry Select, 1: 605-6061. DOI: 10.1002/slct.201601169.

Takama T., Lambe F., Johnson F., Arvidson A., Atanassov B., Debebe M., Nilsson L., Tella P., Tsephel S., 2011. Will African Consumers Buy Cleaner Fuels and Stoves? Research Report, Stockholm Environment

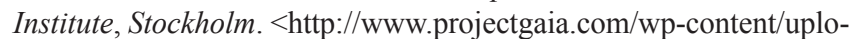
ads/2014/02/SEI-Will-African-Consumers-Buy-Cleaner-Fuels-andStoves-new.pdf $>$ (dostęp: październik 2019).

Wojtowicz R., 2014. Współspalanie biogazu rolniczego i LNG lub LPG jako alternatywa dla zatłaczaniu biogazu do sieci. Praca statutowa nr 0013/ GU/14, Instytut Nafty i Gazu - Państwowy Instytut Badawczy, Kraków.
Zyśk J., Suwała W. (red.), 2017. Skrypt z zakresu energetyki, ochrony powietrza i emisji z pojazdów. Akademia Górniczo-Hutnicza im. Stanisława Staszica w Krakowie, Wydziat Energetyki i Paliw.

Żółty M., Sacha D., 2018. Influence of E85 ethanol fuel composition on engine oil properties. Nafta-Gaz, 4: 308-318. DOI: 10.18668/ NG.2018.04.07.

Żółty M., Stępień Z., 2016. Paliwa etanolowe w zastosowaniu do silników o zapłonie iskrowym. Nafta-Gaz, 9: 761-769. DOI: 10.18668/ NG.2016.09.12.

\section{Akty prawne i normatywne}

PN-EN 16647:2015 Kominki na paliwa ciekłe. Urządzenia dekoracyjne wytwarzające płomień przy wykorzystaniu alkoholu na bazie paliwa w postaci żelu. Zastosowanie w prywatnych gospodarstwach domowych.

Rozporządzenie Ministra Gospodarki z dnia 29 stycznia 2013 r. w sprawie ograniczeń produkcji, obrotu lub stosowania substancji i mieszanin niebezpiecznych lub stwarzających zagrożenie oraz wprowadzania do obrotu lub stosowania wyrobów zawierających takie substancje lub mieszaniny (t.j. Dz.U. z 2013 r. poz. 180 z późn. zm.).

Rozporządzenie Ministra Rolnictwa i Rozwoju Wsi z dnia 25 czerwca 2008 r. w sprawie środków dopuszczonych do skażania alkoholu etylowego (t.j. Dz.U. z 2008 r. Nr 120, poz. 776 z późn. zm.).

Rozporządzenie (WE) nr 1907/2006 Parlamentu Europejskiego i Rady $\mathrm{z}$ dnia 18 grudnia 2006 r. w sprawie rejestracji, oceny, udzielania zezwoleń i stosowanych ograniczeń w zakresie chemikaliów (REACH) i utworzenia Europejskiej Agencji Chemikaliów, zmieniające dyrektywę 1999/45/WE oraz uchylające rozporządzenie Rady (EWG) nr 793/93 i rozporządzenie Komisji (WE) nr 1488/94, jak również dyrektywę Rady 76/769/EWG i dyrektywy Komisji 91/155/EWG, 93/67/ EWG, 93/105/WE i 2000/21/WE (Tekst mający znaczenie dla EOG).

Ustawa z dnia 11 stycznia 2018 r. o elektromobilności i paliwach alternatywnych (t.j. Dz.U. z 2018 r. poz. 317 z późn. zm.).

Ustawa z dnia 15 lutego 2015 r. o odnawialnych źródłach energii (t.j. Dz.U. z 2015 r. poz. 478 z późn. zm.).

Ustawa z dnia 2 marca 2001 r. o wyrobie alkoholu etylowego oraz wytwarzaniu wyrobów tytoniowych (t.j. Dz.U. z 2001 r. Nr 31, poz. 353 $\mathrm{z}$ późn. zm.).

Ustawa z dnia 10 kwietnia 1997 r. - Prawo energetyczne (t.j. Dz.U. z 1997 r. Nr 54, poz. 348 z późn. zm.).

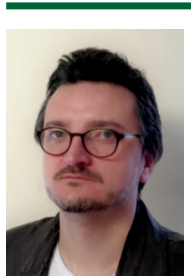

Mgr inż. Maciej BASIURA

Asystent w Zakładzie Użytkowania Paliw

Instytut Nafty i Gazu - Państwowy Instytut Badawczy ul. Lubicz 25 A

31-503 Kraków

E-mail: maciej.basiura@inig.pl

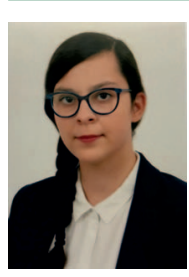

Mgr inż. Urszula ŻYJEWSKA

Specjalista inżynieryjno-techniczny w Zakładzie Użytkowania Paliw

Instytut Nafty i Gazu - Państwowy Instytut Badawczy

ul. Lubicz 25 A

31-503 Kraków

E-mail: urszula.zyjewska@inig.pl

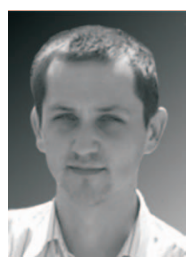

Mgr inż. Tomasz SIUDA

Specjalista inżynieryjno-techniczny w Zakładzie Użytkowania Paliw

Instytut Nafty i Gazu - Państwowy Instytut Badawczy ul. Lubicz $25 \mathrm{~A}$

31-503 Kraków

E-mail: tomasz.siuda@inig.pl 